\title{
Occurrence of ochratoxin A in animal tissues and feeds in Poland in 2014-2016
}

\author{
Katarzyna Pietruszka, Marta Piątkowska, Piotr Jedziniak \\ Department of Pharmacology and Toxicology, \\ National Veterinary Research Institute, 24-100 Pulawy \\ katarzyna.pietruszka@piwet.pulawy.pl
}

Received: September 14, 2017 Accepted: December 8, 2017

\begin{abstract}
Introduction: Ochratoxin A (OTA) is a toxic metabolite mainly produced by Aspergillus spp. and Penicillum spp. fungi. Research on the contamination of cereals, complete feeds, and tissues with this mycotoxin has indicated that it can be a toxicological problem impacting animal health and food safety in temperate climes. OTA contamination mainly besets the global pig industry, necessitating the monitoring of feeds and animal tissues. The aim of the study was to present the results of the official monitoring of OTA in animal tissues and feeds in Poland in 2014-2016 and determine the possible correlation between the presence of OTA in different types of samples. Material and Methods: The presence of ochratoxin A was determined using accepted procedures based on liquid chromatography with fluorescence detection after immunoaffinity column clean-up. Determination of OTA was afforded in the range of $0.3 \mu \mathrm{g} / \mathrm{kg}$ to $300 \mu \mathrm{g} / \mathrm{kg}$ in complete feeds and from $0.2 \mu \mathrm{g} / \mathrm{kg}$ to $150 \mu \mathrm{g} / \mathrm{kg}$ in the kidneys, liver, and muscles. Results: Over the three year span, about $23.5 \%$ of the animal tissues samples were contaminated by ochratoxin A. In the 2014 survey, $10 \%$ of the sample tissues contained 5-10 $\mu \mathrm{g} / \mathrm{kg}$ (only one sample above $10 \mu \mathrm{g} / \mathrm{kg}$ ), and in 2015 and 2016, 24\% of samples showed levels above the limit of quantification $0.2 \mu \mathrm{g} / \mathrm{kg}$, while none of the samples exceeded the established provisional action level of $5 \mu \mathrm{g} / \mathrm{kg}$ for animal tissues. The animal feed analysis showed that $9 \%$ was contaminated with ochratoxin A above the limit of quantification of $0.3 \mu \mathrm{g} / \mathrm{kg}$. In $2 \%$ of feed samples the OTA concentration was greater than $50 \mu \mathrm{g} / \mathrm{kg}$. Conclusion: The results confirm the appropriacy of OTA contamination monitoring and help to increase food safety.
\end{abstract}

Keywords: feeds, animal tissues, ochratoxin A, chromatography, national monitoring.

\section{Introduction}

Ochratoxin A (OTA) is a secondary metabolite containing chlorinated dihydroisocoumarin moiety in its molecule, produced by different species of Aspergillus spp. and Penicillium spp. (15). Based on sufficient evidence for carcinogenicity in experimental animal studies it has been recognised by the International Agency for Research on Cancer (IARC) as a possible human carcinogen and classified into group 2B $(14,17,21)$.

OTA may be extensively distributed in agricultural commodities and in the environment. Contamination of foods with this mycotoxin, particularly of cereals, nuts, and coffee beans, has been noted in Eastern and Central Europe, North Africa, North America, and Japan (5, 14, 19). OTA accumulates in the body, especially in the kidneys as its target organ, where it exerts toxic and carcinogenic effects $(1,12,13)$. In the light of the evidence of OTA's toxicity, its presence in food and feeds is undesirable.
To reduce the health risks posed by the mycotoxin contamination of food and feed, legal restrictions are placed on these commodities. Currently, EC Regulations No 1881/2006 and No 576/2006 (7, 9) and later amendments are in force in Poland, establishing recommended levels allowable for OTA presence in food and setting indicative values for feed ingredients. In Poland the recommended level (ML) adopted for animal tissues (kidneys, liver, and muscles) is set at $5 \mu \mathrm{g}$ OTA per kg; and for feedstuffs, MLs are set at $50 \mu \mathrm{g} / \mathrm{kg}$ for complementary and complete feeds for pigs, $100 \mu \mathrm{g} / \mathrm{kg}$ for poultry feeds, and $250 \mu \mathrm{g} / \mathrm{kg}$ for cereals and cereal based products $(6,7)$.

As controlling the presence of OTA in the food chain is an important part of food safety, it was included in The National Residue Control Plan (NRCP) for Chemical, Biological, and Drug Residue in Animal Tissues and in the Food of Animal Origin mandatory in all countries of the European Union, according to Annex I of Council Directive 96/23/EC of 29 April (4). 
The Polish monitoring programme for the presence of OTA in animal tissues according to Council Directive 96/23 has been implemented for many years only by the Department of Pharmacology and Toxicology of the National Veterinary Research Institute. In Poland, the presence of OTA in feeds and feed materials is monitored by the implementation of a feed control programme, fulfilled by six regional veterinary inspection laboratories. Feed samples for the control tests are collected by the Veterinary Inspectorate and sent to a designated laboratory. Subsequently the results of OTA testing of feeds and feed materials are reported to the National Reference Laboratory of the National Veterinary Research Institute.

In this paper the results of the Polish official monitoring of OTA residues in food of animal origin and feeds covering the years 2014-2016 are presented. The study is a continuation of the research carried out between 2003 and 2012 and published in 2013 (20).

\section{Material and Methods}

OTA was determined using validated and accredited procedures according to EU requirements $(4,8)$.

Sampling. In 2014-2016, a total of 300 feed samples and 430 samples of swine kidneys, poultry liver, and fish muscles from all over the country were tested for the presence of OTA. The sampling of the materials was performed under the NRCP in accordance with the internal instruction of the Chief Veterinary Officer. Tissue samples were kept frozen below $-18^{\circ} \mathrm{C}$ until the day of analysis.

Reagents and chemicals. All chemicals were of HPLC grade. OchraTest WB immunoaffinity columns (IAC) were purchased from VICAM Inc (USA). Ochratoxin A standard and all other reagents obtained from Sigma-Aldrich (USA) were of minimum 99\% purity. Methanol, acetonitrile, toluene, and acetic acid were obtained from J.T. Baker (USA). Water was obtained from a Milli-Q Advantage system (Millipore, USA). A stock solution of OTA $(1,000 \mu \mathrm{g} / \mathrm{mL})$ was prepared in a toluene-acetic acid mixture $(99: 1, \mathrm{v} / \mathrm{v})$ and stored in the dark at $-16^{\circ} \mathrm{C}$ or below for a maximum of six months. The OTA working standard solutions were prepared by appropriate dilution of the stock solution in mobile phase for LC analysis (acetonitrile-water-0.1\% acetic acid, 495:195:10, v/v/v) and stored in the dark at $6^{\circ} \mathrm{C}$ or below for a maximum of three months.

Extraction and clean-up of animal tissues. A $10 \mathrm{~g}$ tissue sample (kidneys, muscles, or liver) was homogenised with $50 \mathrm{~mL}$ of chloroform. The sample was then centrifuged at $3,500 \mathrm{rpm}$ for $15 \mathrm{~min}$ at $-4^{\circ} \mathrm{C}$ and filtered. Next, the eluate was evaporated by rotary evaporator and the residue was dissolved in methanol. Whole extract was taken for clean-up using the SPE technique and OchraTest WB immunoaffinity columns. Afterwards, the eluate was dried under a gentle stream of nitrogen at $35 \pm 5^{\circ} \mathrm{C}$ and subjected to chromatographic analysis.
Extraction and clean-up of feeds and feed materials. A $25 \mathrm{~g}$ feed sample was rotary shaken with methanol-water mixture, 80:20 (v/v), for $1 \mathrm{~h}$. The solution was next centrifuged at 3,500 rpm for $15 \mathrm{~min}$ at $-4^{\circ} \mathrm{C}$. The extract was filtered and $15 \mathrm{~mL}$ of it was diluted with $60 \mathrm{~mL}$ of water. Subsequently, the diluted extract was taken for clean-up by SPE technique and OchraTest WB immunoaffinity columns. Then the eluate was dried under a gentle stream of nitrogen at $35 \pm 5^{\circ} \mathrm{C}$ and subjected to chromatographic analysis.

Liquid chromatography-fluorescence detection. The liquid chromatograph (Agilent 1100 Series, Agilent, Germany) was coupled to a fluorescence detector with excitation wavelength of $\lambda_{\mathrm{ex}}=340 \mathrm{~nm}$ and emission wavelength of $\lambda_{\mathrm{em}}=470 \mathrm{~nm}$. Chromatographic separation was performed using the column Inertsil ODS-3 $(5 \mu, 150 \mathrm{~mm} \times 4.6 \mathrm{~mm}$, Phenomenex, USA). The mobile phase for LC analysis consisted of acetonitrile-water-acetic acid (495:495:10, $\mathrm{v} / \mathrm{v} / \mathrm{v}$ ) mixture in isocratic elution with a flow rate of $1.4 \mathrm{~mL} / \mathrm{min}$ at ambient temperature. The software used for data operation was ChemStation Rev.A.10.1 (Agilent, Germany).

Validation procedures. To perform the validation procedures, animal tissues and feed samples were spiked with OTA at the levels of 2.5, 5.0, and $7.5 \mu \mathrm{g} / \mathrm{kg}$ and processed through the appropriate extraction procedures described above. The following parameters were established: linearity (working range), limit of detection (LOD), limit of quantification (LOQ), recovery, repeatability $(\mathrm{CV})$, within-laboratory reproducibility $(\mathrm{CV})$, and uncertainty $\left(\mathrm{U}_{\mathrm{c}}\right.$ for spiking level $\mathrm{C}=5 \mu \mathrm{g} / \mathrm{kg})($ Table 1$)$.

\section{Results}

The validation results, which are in line with the requirements for mycotoxin assays in animal feed and tissues, are presented in Table 1.

The feed analysis showed that out of the 300 tested samples, 27 samples were contaminated with OTA above the limit of quantification (LOQ) of $0.3 \mu \mathrm{g} / \mathrm{kg}$ (Table 2). Fifteen of them contained OTA in concentrations ranging from 0.3 to $10 \mu \mathrm{g} / \mathrm{kg}$ and in seven samples the concentration ranged from 10 to $50 \mu \mathrm{g} / \mathrm{kg}$. Five samples exceeded the established maximum level in feed set at $50 \mu \mathrm{g} / \mathrm{kg}$ (maximum detected concentration of OTA: $222 \mu \mathrm{g} / \mathrm{kg}$ ) (Fig. 1).

Over the three years under consideration, in Poland $23.5 \%$ of analysed tissue samples were contaminated with OTA (Table 3). Out of 430 tissue samples tested for the presence of OTA, 94 were contaminated at the levels of $0.2-5 \mu \mathrm{g} / \mathrm{kg}$. The concentrations reached the provisional action level (set in Poland at $5 \mu \mathrm{g} / \mathrm{kg}$ ) in seven samples (four samples with OTA at concentrations of 5-10 $\mu \mathrm{g} / \mathrm{kg}$ and three samples at concentrations above $10 \mu \mathrm{g} / \mathrm{kg}$ ) (Fig. 2). 
Table 1. Results of the method validation

\begin{tabular}{|c|c|c|c|c|c|c|c|c|c|c|c|c|}
\hline Parameter & \multicolumn{3}{|c|}{ Feed } & \multicolumn{3}{|c|}{ Kidneys } & \multicolumn{3}{|c|}{ Liver } & \multicolumn{3}{|c|}{ Muscles } \\
\hline Working range $(\mu \mathrm{g} / \mathrm{kg})$ & \multicolumn{3}{|c|}{$0.3-300$} & \multicolumn{3}{|c|}{$0.2-150$} & \multicolumn{3}{|c|}{$0.2-150$} & \multicolumn{3}{|c|}{$0.2-150$} \\
\hline $\mathrm{LOD}(\mu \mathrm{g} / \mathrm{kg})$ & \multicolumn{3}{|c|}{0.1} & \multicolumn{3}{|c|}{0.13} & \multicolumn{3}{|c|}{0.12} & \multicolumn{3}{|c|}{0.11} \\
\hline LOQ $(\mu \mathrm{g} / \mathrm{kg})$ & \multicolumn{3}{|c|}{0.31} & \multicolumn{3}{|c|}{0.2} & \multicolumn{3}{|c|}{0.21} & \multicolumn{3}{|c|}{0.26} \\
\hline Spiking level $(\mu \mathrm{g} / \mathrm{kg})$ & 2.5 & 5.0 & 7.5 & 2.5 & 5.0 & 7.5 & 2.5 & 5.0 & 7.5 & 2.5 & 5.0 & 7.5 \\
\hline Recoveries (\%) & 93 & 83 & 84 & 98 & 72 & 67 & 72 & 65 & 73 & 75 & 78 & 70 \\
\hline Repeatability (CV) & 5.2 & 1.4 & 3.7 & 5.2 & 1.4 & 3.7 & 9.5 & 4.0 & 3.9 & 10.1 & 7.0 & 1.5 \\
\hline Reproducibility (CV) & 10.1 & 7.8 & 6.9 & 10.1 & 7.8 & 6.9 & 12.2 & 12.0 & 7.7 & 16.4 & 11.5 & 17.6 \\
\hline Uncertainty $(\mu \mathrm{g} / \mathrm{kg})$ & \multicolumn{3}{|c|}{$\mathrm{U}_{\mathrm{c}}(\mathrm{y})=0.55 ; \mathrm{k}=2, \mathrm{U}=1.1$} & \multicolumn{3}{|c|}{$\mathrm{U}_{\mathrm{c}}(\mathrm{y})=1.1 ; \mathrm{k}=2, \mathrm{U}=2.2$} & \multicolumn{3}{|c|}{$\mathrm{U}_{\mathrm{c}}(\mathrm{y})=0.85 ; \mathrm{k}=2, \mathrm{U}=1.7$} & \multicolumn{3}{|c|}{$\mathrm{U}_{\mathrm{c}}(\mathrm{y})=0.77 ; \mathrm{k}=2, \mathrm{U}=1.5$} \\
\hline
\end{tabular}

Table 2. Ochratoxin A levels in feeds determined in the national feed monitoring

\begin{tabular}{lllllll}
\hline Year & $\begin{array}{l}\text { Number } \\
\text { of analysed } \\
\text { samples }\end{array}$ & $\begin{array}{l}\text { Number } \\
\text { of positive } \\
\text { results }\end{array}$ & \multicolumn{2}{l}{$\begin{array}{l}\text { Number of sample } \\
\text { of OTA residues }(\mu \mathrm{g} / \mathrm{kg}) \\
\geq 0.3-10\end{array}$} & $\begin{array}{l}\text { Average concentration } \\
\text { of OTA } \pm \text { SD }(\mu \mathrm{g} / \mathrm{kg})\end{array}$ \\
\hline 2014 & 95 & 4 & 3 & $\mathrm{nd}^{*}$ & 1 & $19.8 \pm 2.0$ \\
\hline 2015 & 94 & 11 & 6 & 3 & 2 & $38.3 \pm 3.9$ \\
\hline 2016 & 111 & 12 & 6 & 4 & 2 & $23.9 \pm 24.1$ \\
\hline Total & 300 & 27 & 15 & 7 & 5 & $27.3 \pm 2.8$ \\
\hline Total $(\%)$ & 100 & 9 & 5 & 3 & 2 & \\
\hline
\end{tabular}

*nd - not detected

Table 3. Ochratoxin A levels in animal tissues determined in the national tissue monitoring

\begin{tabular}{lllllll}
\hline Year & $\begin{array}{l}\text { Number } \\
\text { of analysed } \\
\text { samples }\end{array}$ & $\begin{array}{l}\text { Number } \\
\text { of positive } \\
\text { results }\end{array}$ & \multicolumn{3}{l}{$\begin{array}{l}\text { Number of tissue samples } \\
\text { of OTA residues }(\mu \mathrm{g} / \mathrm{kg})\end{array}$} & $\begin{array}{l}\text { Average concentration } \\
\text { of OTA } \pm \text { SD }(\mu \mathrm{g} / \mathrm{kg})\end{array}$ \\
\hline 2014 & 134 & 30 & 26 & 3 & 1 & $2.6 \pm 0.5$ \\
\hline 2015 & 156 & 37 & 34 & 1 & 2 & $2.0 \pm 0.4$ \\
\hline 2016 & 140 & 34 & 34 & $\mathrm{nd}^{*}$ & $\mathrm{nd}^{*}$ & $1.5 \pm 0.3$ \\
\hline Total & 430 & 101 & 94 & 4 & 3 & $2.0 \pm 0.4$ \\
\hline Total $(\%)$ & 100 & 23.5 & 22 & 1 & 1 & \\
\hline
\end{tabular}

*nd - not detected

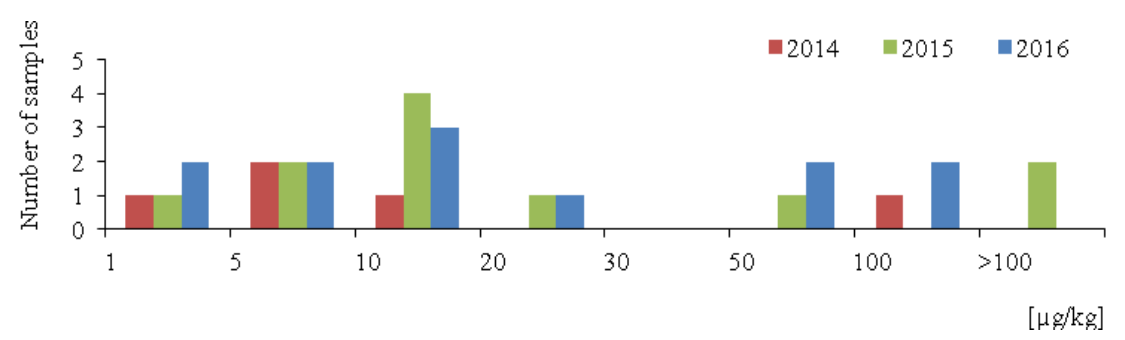

Fig. 1. Distribution of OTA contamination in feeds in Poland in the years 2014-2016

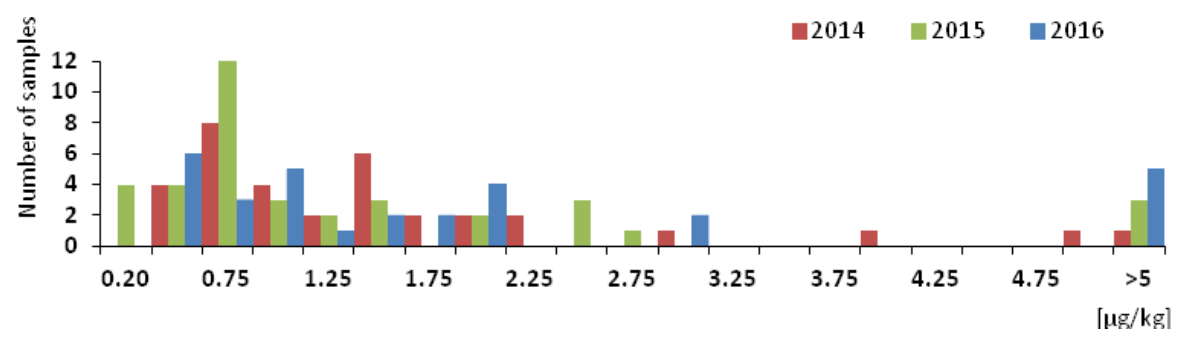

Fig 2. Distribution of OTA contamination in tissues in Poland in the years 2014-2016 
Table 4. The residues of OTA in the kidneys after prior exposure to OTA in feed

\begin{tabular}{lllll}
\hline Authors & Animals & $\begin{array}{l}\text { OTA dose } \\
\text { (feed) }\end{array}$ & $\begin{array}{l}\text { Exposure time } \\
\text { (days) }\end{array}$ & $\begin{array}{l}\text { Concentration of OTA } \\
\text { (kidneys) }\end{array}$ \\
\hline Zhang et al. (22) & weaned pigs (weight $10 \mathrm{~kg})$ & $800 \mu \mathrm{g} / \mathrm{kg}$ & 42 & $400 \mu \mathrm{g} / \mathrm{kg}$ \\
\hline Bernardini et al. (2) & weaned pigs (weight $10 \mathrm{~kg})$ & $181 \pm 34 \mu \mathrm{g} / \mathrm{kg}$ & 43 & $21.91 \pm 2.17 \mu \mathrm{g} / \mathrm{kg}$ \\
\hline Perši et al. (16) & weaned pigs (weight $10 \mathrm{~kg})$ & $300 \mu \mathrm{g} / \mathrm{kg}$ & 30 & $15.31 \pm 3.11 \mu \mathrm{g} / \mathrm{kg}$ \\
\hline
\end{tabular}

\section{Discussion}

Animals are continuously exposed to OTAcontaminated feeds, as OTA is one of the most often detected mycotoxins in animal feeds and feed components, whereas humans are mainly exposed to OTA via food and beverages $(3,11)$. The dietary exposure for adult consumers in the EU has been estimated at $0.015-0.06 \mu \mathrm{g} / \mathrm{kg}$ b.w. per week (10). Considering its toxic effects both to animals and humans, the standardisation of allowable OTA content in food and feed for the EU countries and the implementation of annual national monitoring programmes are crucial. A number of countries, particularly in Europe, have already implemented regulations governing the OTA presence in food and feed.

Most of the regulations set the maximum permitted or recommended levels for specific commodities. National legislation for OTA in products of animal origin exists in three countries. The Italian Ministry of Health has established an OTA maximum level of $1 \mu \mathrm{g} / \mathrm{kg}$ for pig meat and derived products (16). Estonia has accepted $10 \mu \mathrm{g} / \mathrm{kg}$ for pig liver. In Denmark, if OTA content in the kidneys is higher than $25 \mu \mathrm{g} / \mathrm{kg}$, the whole carcass is rejected, because the meat is assumed to be highly contaminated; if the OTA concentration is between 10 and $25 \mu \mathrm{g} / \mathrm{kg}$, edible offal is eliminated; but if the mycotoxin in kidney tissue is lower than $10 \mu \mathrm{g} / \mathrm{kg}$, only the kidneys are discarded. However, most EU countries, including Poland, have adopted an action level of $5 \mu \mathrm{g} / \mathrm{kg}(6)$.

The experimental studies carried out on pigs demonstrated that the concentrations of OTA detected in the kidneys after the administration of OTAcontaminated feed varied from $5 \%$ to $50 \%$ of the dose given to animals (Table 4 ). These studies show the cooccurrence of OTA in feeds and in animal tissues in animals supplied feed contaminated with OTA $(2,16$, 22). Therefore, it can be concluded that in Poland during the years 2014-2016 the persistently low, but constant level of OTA in swine tissues indicates the continuous presence of this mycotoxin in feeds. In the light of recent studies, even a low level of feed contamination $(50 \mu \mathrm{g} / \mathrm{kg})$ may activate the pig immune and oxidative stress response as well as the early carcinogenic events (12). However, pigs are very sensitive to mycotoxin intoxication and such effects need to be further investigated in humans (19).

OTA effects on the exposed organism are strongly dependent not only on OTA dose and exposure time, but also on contamination type (natural or artificial). Some studies have shown that concentrations of OTA in serum, kidneys, liver, and muscle tissues in pigs fed naturally contaminated OTA feeds may be 3-5 times higher than in animals fed OTA-artificially contaminated feed (16). The results of the studies suggest that persistent exposure of pigs to OTA in feed may be the cause of nephropathy in the animals and may increase the risk of consumer exposure to OTA.

In our study, for the three years to the end of 2016 the average level of the OTA concentration in feeds was $27.3 \mu \mathrm{g} / \mathrm{kg}$, whereas in animal tissues it was $2 \mu \mathrm{g} / \mathrm{kg}$ (below the action levels of $5 \mu \mathrm{g} / \mathrm{kg}$ in animal tissues and $50 \mu \mathrm{g} / \mathrm{kg}$ in feeds). The results of the studies show that there is a possible correlation between the level of OTA in feeds and residues in animal tissues. The continuous monitoring of OTA contamination of pig feed is necessary to guarantee the animals' health, reduce economic losses, and ensure the safety of animal-derived food.

In 2014, 28 European Union Member States reported results for mycotoxins in 1,968 target samples analysed in pigs under their national monitoring plans. Of 117 non-compliant results for mycotoxins (B3d group) 7 were reported as non-compliant for OTA. The noncompliant samples were reported by 19 Member States. The results of the Greek report in the EFSA of 2014 show that of the 24 analysed samples, 9 were noncompliant (37.5\%) (18).

In Poland, OTA was determined using validated and accredited procedures, based on liquid chromatography with fluorescence detection after immunoaffinity column clean-up. Based on our obtained and published results from 2003 to 2012, the incidence of positive samples was from 24 to 41 in different years (20). In the study time frame the percentage of noncompliant samples $(\geq 5 \mu \mathrm{g} / \mathrm{kg}$ ) varied from $1 \%$ in 2011 to $9.9 \%$ in 2004 . Only in 2010 were there no noncompliant samples. The percentage of positive kidney samples containing OTA over the limit of quantification $(\mathrm{LOQ}=0.2 \mu \mathrm{g} / \mathrm{kg}$ ) in 2006 was $5 \%$, in 2007 it was $6 \%$, in 2009 it was $10 \%$, while the highest of $39 \%$ was in 2008 (20). In Poland in the most recent years OTA was detected annually on average in $22.3 \%$ of tissue samples (2014), in $23.7 \%$ of samples (2015), and in $23.7 \%$ of samples (2016). However, in about $2 \%$ of animal tissue samples the OTA concentration was greater than $5 \mu \mathrm{g} / \mathrm{kg}$ (Fig. 2).

Summing up, the results of our studies showed a low but constant level of feed contamination with OTA (average concentration $27.3 \mu \mathrm{g} / \mathrm{kg}$, range from 1 to 
$222 \mu \mathrm{g} / \mathrm{kg}$ ) and low and constant levels of OTA present in animal tissues (average concentration $2.0 \mu \mathrm{g} / \mathrm{kg}$, range from 0.2 to $21.5 \mu \mathrm{g} / \mathrm{kg}$ ). The results of the study are consistent with the results of the studies conducted between 2003 and 2012 and published in 2013.

Low levels of OTA in feed suggest low exposure of animals to this mycotoxin and low levels of OTA in tissues demonstrate that exposure of Polish consumers via food of animal origin approximates the average for consumer exposure for humans in the EU countries.

Conflict of Interests Statement: The authors declare that there is no conflict of interests regarding the publication of this article.

Financial Disclosure Statement: The investigation was supported by the Polish Ministry of Agriculture and Rural Development under the auspices of the Multiannual Programme "Control of the presence of prohibited substances in food of animal origin and undesirable substances in animal feed".

Animal Rights Statement: None required.

\section{References}

1. Aoudia N., Callu P., Grosjean F., Larondelle Y.: Effectiveness of mycotoxin sequestration activity of micronized wheat fibres on distribution of ochratoxin A in plasma, liver and kidney of piglets fed a naturally contaminated diet. Food Chem Toxicol 2009, 47, 1485-1489.

2. Bernardini C., Grilli E., Duvigneau J.C., Zannoni A., Tugnoli B., Gentilini F., Bertuzzi T., Spinozzi S., Camborata C., Bacci M.L., Piva A., Forni M.: Cellular stress marker alteration and inflammatory response in pigs fed with an ochratoxin contaminated diet. Res Vet Sci 2014, 97, 244-250.

3. BIOMIN Word Mycotoxin Survey 2016. Annual Report No.13. Available online: http://www.pigbusiness.nl/upload/files/ 1488236289MAG_MTXsurveyReport_2016_EN_0117_PKO.pdf.

4. Commission Decision 2002/657/EC of 12 August 2002 implementing Council Directive 96/23/EC concerning the performance of analytical methods and the interpretation of results. Off J Eur Commun 2002, 221, 8-36.

5. Dragacci S., Grosso F., Bire R., Fremy J.M., Coulon S.: A French monitoring programme for determining ochratoxin A occurence in pig kidneys. Nat Toxins 1999, 7, 167-173.

6. EFSA, Opinion of the scientific panel on contaminants in the food chain on a request from the commission related to ochratoxin $\mathrm{A}$
(OTA) as undesirable substance in animal feed. Adopted on 22 September 2004. EFSA J 2004, 101, 1-36.

7. European Commission Recommendation No 576/2006 of 17 August 2006 on the presence of deoxynivalenol, zearalenone, ochratoxin A, T-2, and HT-2 and fumonisins in products intended for animal feeding Off J Eur Commun 2006, 229, 7-9.

8. European Commission Regulation No 401/2006 of 23 February 2006 laying down the methods of sampling and analysis for the control of the levels of mycotoxins in foodstuffs. Off $\mathrm{J}$ Eur Commun 2006, 70, 12-35.

9. European Commission Regulation No 1881/2006 of 16 December 2006 setting maximum levels for certain contaminants in foodstuffs. Off J Eur Commun 2006, 364, 5-24.

10. Heussner A., Bingle L.: Comparative ochratoxin toxicity: a review of the available data. Toxins 2015, 7, 4253-4282.

11. Krska R., Nährer K., Richard J.L., Rodrigues I., Schuhmacher R., Slate A.B., Whitaker T.B.: Guide to mycotoxins featuring mycotoxin risk management in animal production. BIOMIN, Austria 2012.

12. Marin D.E., Braicu C., Gras M.A., Pistol G.C., Petric R.C., Berindan N.I., Palade M., Taranu I.: Low level of ochratoxin A affects genome - wide expression in kidney of pig. Toxicon 2017, 136, 67-77.

13. Marin S., Ramos A.J., Cano-Sancho G., Sanchis V.: Mycotoxins: occurrence, toxicology, and exposure assessment. Food Chem Toxicol 2013, 60, 218-237.

14. Mitchell N.J., Chen C., Palumbo J.D., Bianchini A., Cappozzo J., Stratton J., Ryu D., Wu F.: A risk assessment of dietary ochratoxin $\mathrm{a}$ in the United States. Food Chem Toxicol 2017, 100, 265-273.

15. Naohiko A., Promsuk J., Hitoshi E.: Molecular mechanism of ochratoxin A transport in the kidney. Toxins 2010, 2, 1381-1398.

16. Perši N., Pleadin J., Kovačević D., Scortichini G., Milone S.: Ochratoxin A in raw materials and cooked meat products made from OTA - treated pigs. Meat Sci 2014, 96, 203-210.

17. Pfohl-Leszkowicz A., Manderville R.A. Ochratoxin A: An overview on toxicity and carcinogenicity in animals and humans. Mol Nutr Food Res 2007, 51, 61-99.

18. Report for 2014 on the results from the monitoring of veterinary medicinal product residues and other substances in live animals and animal products. European Food Safety Authority (EFSA), 2016.

19. Smith M.C., Madec S., Coton E., Hymery N.: Natural cooccurrence of mycotoxins in foods and feeds and their in vitro combined toxicological effects. Toxins 2016, 94, 1-36.

20. Wiśniewska-Dmytrow H., Żmudzki J., Burek O., Pietruszka K.: Official control of ochratoxin A in food of animal origin in Poland between 2003 and 2012. Bull Vet Inst Pulawy 2013, 57, 519-523.

21. Wiśniewska-Dmytrow H., Żmudzki J., Pietruszka K., Burek O.: Occurrence of ochratoxin A in organs, muscle tissue, and digestive tract content of wild game. Med Weter 2015, 71, 436-440.

22. Zhang Z., Gan F., Xue H., Liv Y., Huand D., Khan A.Z., Chen X., Huang K.: Nephropathy and hepatopathy in weaned piglets provoked by natural ochratoxin A and involved mechanisms. Exp Toxicol Pathol 2016, 68, 205-213. 